Postprint manuscript - accepted version

(published Current Opinion in Oncology: May 25, 2021 doi: 10.1097/CCO.0000000000000755

Novel next-generation sequencing-based methodologies to characterize the mutational consequences of (prenatal) chemotherapy exposure in noncancerous tissue.

\title{
Authors
}

Ilana Struys ${ }^{1}$, Liesbeth Lenaerts ${ }^{1}$, Bernard Thienpont ${ }^{2}$, Frédéric Amant ${ }^{1,3,4}$

${ }^{1}$ Department of Oncology, KU Leuven, Herestraat 49, Leuven, Belgium

${ }^{2}$ Department of Human Genetics, KU Leuven, Herestraat 49, Leuven, Belgium

${ }^{3}$ Gynecologic Oncology, Netherlands Cancer Institute, Plesmanlaan 121, Amsterdam, The Netherlands

${ }^{4}$ Gynecologic Oncology, Amsterdam University Medical Centers, Meibergdreef 9, Amsterdam, The Netherlands

\section{Address corresponding author}

Frédéric Amant, MD, PhD

KU Leuven

Herestraat 49

3000 Leuven

Belgium

E-mail: frederic.amant@uzleuven.be

Phone: +32 16344635 


\begin{abstract}
Purpose of review: Although chemotherapeutics are considered as genotoxins for decades, their exact mutagenic impact on the genome of cancerous and normal cells of cancer patients was unknown for a long time. However, this knowledge is necessary to understand the long-term side effects of chemotherapy. A particular condition represents pregnant cancer patients being treated with chemotherapy. Since certain chemotherapeutics can cross the placenta, concerns exist about possible mutational effects on the fetus' genome with potential long-term health consequences.

Recent findings: Recent advances of next-generation sequencing techniques have opened possibilities to explore the exact mutational footprint of chemotherapies in healthy tissue from treated cancer patients. However, the ultra-low frequency of chemotherapy-induced mutations, introduction of technical artefacts and inaccessibility of normal tissue have posed important limitations. This review discusses five state-of-the-art approaches that were recently designed to overcome these drawbacks. Summary: Results of the latest investigations give valuable insights into the genome-wide genotoxicity profile of frequently applied chemotherapies, with most of these drugs being associated with a signature of random base substitutions and small indels. Though these findings still might be limited to extrapolate to healthy tissue, they pave the way for studies on the origin of long-term chemotherapy-related adverse health effects.
\end{abstract}

Keywords: Cancer, Chemotherapy, Non-cancerous tissue, Next-generation sequencing, Mutational signature 
Postprint manuscript - accepted version

\section{Introduction}

Despite improved efficacy and enhanced survival rates resulting from modern anticancer treatments, side effects and long-term sequelae of chemotherapy remain a major concern. Chemotherapeutics typically interfere with cell growth- and survival-related processes and have the ability to (in)directly interact with the cancer cell's genetic material (Table 1) [1]. After erroneous DNA replication or repair, chemotherapy-induced DNA lesions might result in the acquisition of de novo point mutations (base substitutions, small indels) and large structural variations (SVs, copy number alterations (CNAs), translocations and inversions). Since classical chemotherapeutics have relatively low tumor specificity, they can also interfere with processes active in healthy cells, hence causing numerous severe shortterm side effects like hair loss, hematologic toxicity and gastrointestinal and/or excretory system disorders [1-3**]. Additionally, chronic and even long-term effects, like an increased risk of developing secondary malignancies and premature aging, have been associated with chemotherapy exposure $\left[1,3^{* *}-5\right]$. While increased cell death, triggered by toxic levels of DNA damage, may underlie some of the long-term effects, somatic mutations resulting from DNA damage across tissues probably also contribute. In fact, recent large-scale cancer genome sequencing projects have revealed that more than half the mutations in cancer genomes arise in healthy cells prior to carcinogenesis [6]. However, the exact link between chemotherapy-mediated mutations in healthy cells and long-term health implications remains unknown $[7,8]$.

This knowledge gap can be partly attributed to the historic lack of techniques to accurately detect chemotherapy-induced DNA damage in normal non-cancerous cells. In the past, the genotoxic ability of chemotherapeutics was only measured via indirect and imprecise in vitro cytogenetic tests, either focusing on mutations (in reporter genes) or on chromosome aberrations (via assays like the micronucleus or COMET assay) [9-15]. Although predicting the carcinogenic potential of the tested drug, these tests cannot determine the presence, nor exact genomic location, of genome-wide single and double base substitutions, indels or SVs. The introduction of next-generation sequencing (NGS) enabled sequencing of multiple genomes in parallel. Existing NGS studies on the mutational footprint 
Postprint manuscript - accepted version

of chemotherapeutics have mainly used cancer cells and (cancer) cell lines [16]. Interestingly, these studies demonstrated that chemotherapy-induced mutations occur independently across tissue cells and hence are random and private to each cell $\left[17^{* *}\right]$. This is in contrast to cancer tissue, where chemotherapy-induced mutations can expand to high clonality. Consequently, cataloguing such lowfrequent DNA aberrations from bulk normal non-cancerous cells in vivo is highly challenging [18*], and only starting to be explored. Yet, this knowledge is of crucial importance to explain and predict longterm health effects of chemotherapy in cancer patients. A particularly pertinent condition is that of pregnant cancer patients being treated with chemotherapy $[19,20]$. Data from in vivo, ex vivo and clinical studies have indicated that certain chemotherapeutics can pass the placental barrier, suggesting that the fetus is likely exposed to the genotoxic effects of these chemotherapeutics [2127]. Additionally, mutations introduced earlier in development may be more impactful as they are more likely to be propagated to multiple adult cells as the cell-of-origin proliferates. Because cancer treatment during pregnancy is becoming a standard of care for these patients [28], evaluating this possibility is highly warranted.

Here, we will review recent efforts undertaken to catalogue the genome-wide mutational footprints of chemotherapeutics in non-cancerous tissue of chemotherapy-exposed (pregnant) patients and describe their advantages and limitations.

\section{Mutational footprints of chemotherapy in healthy tissue of cancer patients}

Given the random nature of chemotherapy-induced mutations in non-cancerous tissue, their variant allele frequency (VAF) may fall below the detection limit of standard bulk sequencing [18*]. Hence, only extreme deep bulk sequencing would enable detecting such mutations, yet at extremely high costs and without being able to discern technical noise from signal [29]. Consequently, detailed knowledge about mutagenic effect of chemotherapeutics in somatic cells is still limited today. The following innovative efforts have recently been undertaken to circumvent this issue using either bulk or single-cell-derived approaches (Figure 1). 
Postprint manuscript - accepted version

Deep sequencing of bulk metastatic tumor samples as proxy for healthy tissue

Due to the clonal expansion characteristic of tumor development, low-abundant treatment-induced somatic mutations may become enriched in metastatic tumor cells and hence detectable through bulk whole-genome sequencing ( $106 \times$ sequencing depth). Using this strategy, Pich and colleagues mapped the presence of single-base substitutions, double-base substitutions and indels in over 3,500 metastatic tumors originating from different organs of chemotherapy-treated patients (Figure 1A) $\left[17^{* *}\right]$. To rule out tumor type specific mutations, both treated and untreated samples were compared per treatment type. Only for three platinum-based drugs (carboplatin, cisplatin and oxaliplatin) and two nucleoside metabolic inhibitors (capecitabine and 5-fluorouracil), treatment-associated mutational signatures could be extracted (Table 1). The investigated chemotherapeutics were found to induce 100 times more mutations than the natural aging process in a similar period [17**]. Pich et al. argued that the mutational toxicity identified in these metastatic samples could serve as a proxy for the potential mutational effect of the investigated chemotherapeutics in the patients' healthy tissue. However, differences in rate of cell division and proficiency of DNA repair between cells, as well as pharmacodynamics and drug metabolism, could influence the mutational risk that chemotherapeutics pose for various tissues. Hence, since metastatic tumor samples might react differently to chemotherapeutics than non-cancerous tissues resulting in a differential mutational pattern, results should be interpreted with caution.

\section{Low coverage genome-wide sequencing of bulk primary human cells}

Quispe-Tintaya and colleagues developed an algorithm to quantitatively and accurately detect chemotherapy-induced low abundant SVs (large indels, inversions and/or translocations) from ultralow coverage $\left(\sim 0.3 \times\right.$ sequencing depth) paired-end whole-genome sequencing data $\left[3^{* *}, 5\right]$. The key features of this algorithm are (i) the use of sequencing libraries free from artificial chimeric fragments, and (ii) a novel non-consensus-based SV-calling algorithm $\left[3^{* *}, 5\right]$. This algorithm was applied on sequencing data of actively proliferating or quiescent cultures of primary human dermal fibroblasts 
Postprint manuscript - accepted version

that were in vitro exposed to bleomycin (Figure 1D). A significant increase in SVs was found, which was highest in quiescent cells (Table 1). This observation was confirmed in post-mitotic mouse liver and hearth tissue $\left[3^{* *}\right]$. The difference in mutation induction in quiescent versus dividing cells was hypothesized to result from a different employment of DNA repair mechanisms. While DNA doublestrand breaks, resulting from bleomycin exposure, are usually repaired by relatively error-free homologous recombination mechanisms in proliferating cells, quiescent cells apply error-prone nonhomologous end joining mechanisms, possibly leading to significantly higher frequencies of somatic SVs [3**]. Hence, quiescent cells were suggested to be a reservoir for chemotherapy-induced genome rearrangements. However, in vitro chemotherapy exposure of cell cultures might result in differences regarding induced mutations compared to the in vivo exposure experienced by patients who receive systemic chemotherapy treatment. Hence, extrapolation to a patients healthy tissue might be limited.

\section{Clonal expansion of human induced pluripotent stem cell lines}

In their recent work, Kucab et al. assessed mutational signatures induced by various known or suspected environmental carcinogens, including five chemotherapeutics (cisplatin, carboplatin, cyclophosphamide, bleomycin and etoposide), using a human induced pluripotent stem cell line (iPSC) obtained upon reprogramming adult skin cells $\left[30^{* *}\right]$. After chemotherapy exposure of the iPSC cultures, single cells were isolated and cultured into subclones that were subsequently subjected to whole-genome deep bulk sequencing ( $30 \times$ sequencing depth) (Figure 1B). Mutation frequencies of de novo base substitutions, indels, rearrangements and CNAs were determined by comparison to the genome of the primary iPSC parental clone. Rearrangements and CNAs turned out to be limited and uninformative, suggesting a high intolerance to double stranded breaks in these sensitive stem cells. Bleomycin and etoposide failed to induce a significant number of mutations. However, for cisplatin and carboplatin, mutational signatures for single and double base substitutions were extracted, being similar for both chemotherapeutics (Table 1 ) [30**]. As most adult human cell types are terminally differentiated and not amenable to growth in culture media, the use of iPSCs has the advantage to 
Postprint manuscript - accepted version

allow for clonal sequencing in otherwise unculturable cell types. However, the process of reprogramming terminally differentiated cells was previously found to be inherently mutagenic, hence precluding reliable extrapolation of mutagenic signatures found in iPSCs upon chemotherapy exposure to those that would be expected in normal human somatic cells [31].

\section{Clonal expansion of human-derived cancer cell lines}

Boot et al. created clonal cultures of the non-tumorigenic human breast epithelial cell line MCF-10A and the liver cancer cell line HepG2 to determine the cisplatin mutational signature. Single cells from cisplatin-exposed cultures were isolated and expanded for whole-genome sequencing $(\sim 33 \times$ sequencing depth) and mutational analyses (Figure $1 \mathrm{C}$ ) $\left[32^{* *}\right]$. The detected cisplatin single-base substitution signature did not exactly match that found in iPSCs, as described by Kucab [ $\left.30^{* *}\right]$. Subtle differences could be attributed to the usage of different cell lines. Interestingly, the cisplatin signature of single base substitutions in the breast and liver cancer cell line was the same as found by Pich et al. in metastatic tumor cells $\left[17^{* *}\right]$. Similarly as in iPSCs [30**], CNAs or SVs were rarely observed in the investigated cancer cell lines, suggesting that cisplatin does not induce detectable genomic instability [32**]. However, since cell lines are artificial systems engineered to divide indefinitely and with unique gene expression patterns not found in any cell type in vivo, they might not be representative to study the mutational footprint of chemotherapeutics in normal cells [33].

\section{Organoids derived from primary human cells}

Using the ability of singular pluripotent stem cells to form in vitro clonal outgrowths, Christensen et al. generated organoids of healthy intestinal colon stem cells to model the mutational effect of in vitro exposure to 5-fluorouracil (Figure 1E) [34**, 35*, 36]. 5-fluorouracil was found to induce single base substitutions, similar as those reported by Pich et al. (Table 1) [17**,34**]. Based on observed in vivo mutation rates due to ageing (40 mutations/year) and the estimated mutation rate induced by 5fluorouracil treatment found in colon tumors (2,000 mutations/year), it was estimated that each 5fluorouracil treatment (standard therapy of 12 cycles) induces an approximate 50 -fold increase in 
Postprint manuscript - accepted version

oncogenic mutations in colon stem cells in vivo compared to normal, untreated circumstances $\left[34^{* *}, 36\right]$. This equals the additive mutation accumulation due to ageing in normal colon stem cells over 20 years. Since organoids mimic the in vivo organs from which the stem cells originate, this experimental setup might be ideally suited to characterize the mutational footprints of chemotherapyexposed organs. Yet, it should be noted that this approach is restricted to stem and progenitor cell types that have the ability to be cultured. Also, selection bias might arise from the selective outgrowth of particular single cells during culturing. Finally, mutations may be induced by the clonal expansion process itself. Yet, this issue can be countered by taking into account differences in VAFs of in vitro generated mutations versus those present in the cell-of-origin $\left[16,34^{* *}, 37\right]$.

\section{Genotoxicity in fetal DNA upon prenatal exposure to chemotherapy}

Pregnant cancer patients are a particular vulnerable population, as maternal treatment options must be balanced with possible fetal risks $[19,20]$. Accumulating evidence indicates that certain anti-cancer therapies are relatively safe if given during the second or third trimester of pregnancy, without major adverse effects on short-term pediatric outcome [38-41]. Yet, a relationship was found between prenatal chemotherapy exposure and incidence of small for gestational age (SGA) babies, the effect being largest for treatment with platinum-derivatives [41]. SGA can be caused by an inherent small constitution or by improper growth in the uterus due to fetal growth restriction conditions, the latter being associated with higher risks of cardiovascular and metabolic diseases later in life [42]. Data from our group suggest that the latter possibility may be true, since prenatal chemotherapy exposure affects both birth weight and placenta [43]. Furthermore, our pharmacokinetic studies in mice and baboons models demonstrated that chemotherapeutics can cross the placental barrier with passage rates ranging from $0.8-2.4 \%$ for taxanes, over $1-10.8 \%$ for alkylating agents and anthracyclines to $43-56 \%$ for platinum-based compounds $[21-23,27]$. Ex vivo and clinical studies, though obtained in small cohorts of pregnant cancer patients, support these findings [24-26]. Consequently, it might be questioned whether prenatal chemotherapy administration has a genotoxic impact on the fetus' genome and 
Postprint manuscript - accepted version

whether this could be associated to some of the observed outcome effects. So far, in humans, toxic effects of prenatal chemotherapy exposure have only been identified based on observable congenital anomalies in infants and miscarriages [44,45*, own unpublished data]. Over the last decade, only five rodent studies addressed this topic, thereby focusing on cyclophosphamide and etoposide [46-50]. Using basic cytogenetic assays, higher levels of apoptosis, DNA fragmentation and/or gross chromosomal aberrations were found in organs and/or blood from in utero-exposed newborn pups (Table 2). However, important species-related differences in DNA repair mechanisms and genome maintenance render these models ill-suited to study the genetic damage caused by prenatal chemotherapy exposure without prior knowledge of what to expect [51]. Based on the high placental transfer rate of alkylating agents, in particular of platinum-based drugs, and on the observed mutational signatures of these drugs in cancer patients' healthy tissue (cfr above), it might be hypothesized that prenatal exposure to alkylating agents, particularly platinum-based drugs, might confer the highest risk for the fetus' genome. This needs urgent investigation in a clinically relevant setup. As it is difficult to non-invasively obtain fetal primary tissue, the approach used by Christensen et al. [34**], in which stem cells are clonally expanded into organoid structures, might offer a feasible direction to study potential effects of prenatal chemotherapy exposure on fetal DNA derived from stem cells isolated from cord blood or other excrements of the neonate [52].

\section{Conclusions and relevance}

Recent technical revolutions using high-throughput NGS approaches have initiated the accrual of genome-wide somatic mutational loads and spectra in non-cancerous human cells arising upon chemotherapy exposure $[16,37]$. Alkylating agents are mostly investigated and were found to induce mutations in a random pattern. However, the use of artificial cell lines and metastatic tumor samples as surrogates for healthy tissues complicates the interpretation of obtained results. Also, most presented studies rely on the evaluation of cells and tissues that were in vitro exposed to chemotherapy. In fact, none of the above described studies investigated the mutational footprint of 
Postprint manuscript - accepted version

chemotherapy in in vivo exposed primary healthy tissue from chemotherapy-treated patients. Therefore, information obtained here must be complemented with carefully planned prospective studies of healthy cell samples from treated patients and survivors $\left[17^{* *}\right]$. We anticipate that future advances in true single-cell sequencing technologies will provide means for high-throughput profiling of low-frequent somatic mutations in single cells across the human body [16,37]. Furthermore, as studying specific cell types that are difficult to access, may require highly invasive procedures, the evaluation of blood-derived cell-free DNA could offer an alternative [16].

From a clinical point of view, mutational signature analyses of chemotherapeutics will be valuable for assessing the mutational risk of different chemotherapies or to develop prevention strategies $\left[32^{* *}, 34^{* *}\right]$. Since the fetus is at risk of being exposed to chemotherapeutics administered during pregnancy, these analyses could also define which chemotherapeutics are safe for the unborn child. Furthermore, long-term follow-up of the defined mutational signatures in treated cancer patients and prenatally exposed children could provide insight into the mechanisms by which long-term side effects of chemotherapy develop. When the exact link between such signatures and the manifestation of diseases later in life is established, they could serve as prognostic biomarkers.

\section{Key points}

- Since chemotherapy-induced mutations are often random and private to each cell, several difficulties exist in identifying these ultra-low frequent mutations.

- Revolutionary advances conferring NGS-based methodologies have made it possible to extract mutational signatures from human-derived cell lines, metastatic tumor samples and induced pluripotent and adult stem cells exposed to chemotherapeutic drugs.

- Results of these studies provide valuable insights into potential genotoxicity in healthy, noncancerous tissues of chemotherapy-treated cancer patients, as well as the prenatally exposed children of chemotherapy-treated pregnant cancer patients.

- Assessing the mutational profiles of chemotherapeutics in healthy, non-cancerous tissues might open perspectives to mechanistic/epidemiologic studies on the long-term side effects of chemotherapy exposure. 


\section{Acknowledgements}

We would like to thank Silvia Calpe for her assistance with the design of the graphic of this review.

\section{Financial support and sponsorship}

This work was supported by a research grant from "Stichting tegen Kanker" (Foundation against Cancer, FAF-F/2018/1264; to Frédéric Amant) and "Kom op tegen Kanker" (Stand up to Cancer, Emmanuel van der Schueren grant; to Ilana Struys). Frédéric Amant is senior researcher for the Research Fund Flanders (F.W.O).

\section{Conflicts of interest}

None

Figure 1

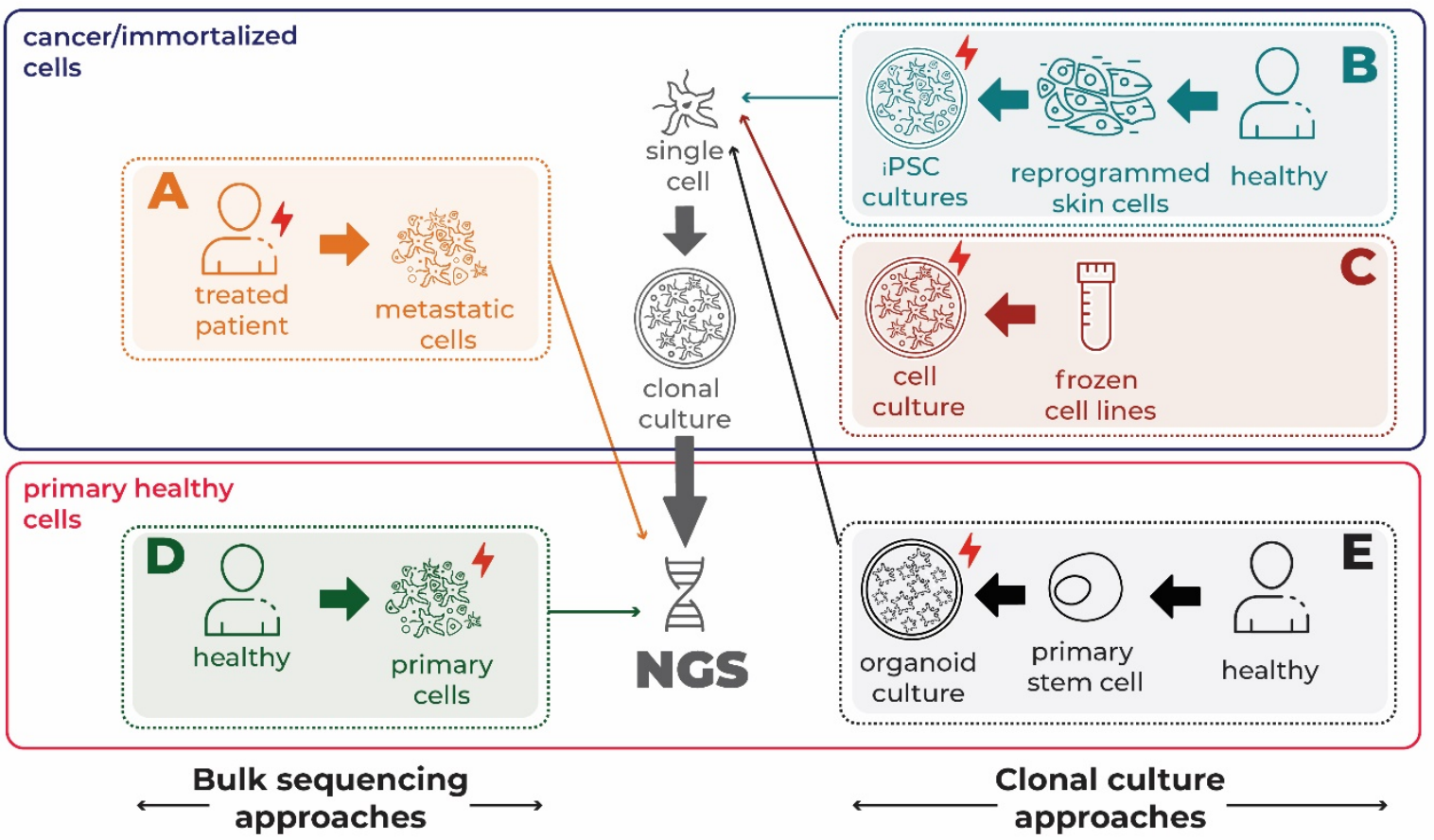

\section{Figure Legends}

Figure 1: Schematic overview of novel Next Generation Sequencing methodologies that are currently applied to characterize the mutational footprint of different chemotherapeutics in surrogates of healthy tissues. A, B and C describe approaches using either cancer cells or immortalized cell lines. A, Bulk sequencing of metastatic tumor cells of chemotherapy-treated patients as a surrogate for healthy normal tissue. This approach was applied by Pich et al. [17**] B, Use of induced pluripotent stem cell (iPSC) cultures that are in vitro exposed to chemotherapy. Next, single cells are expanded into clones for subsequent bulk sequencing [30**]. C, Use of cultured cancer cell lines that are in vitro exposed to chemotherapy, after which single cells are expanded into clones for subsequent bulk sequencing, as applied by Boot et al. [32**] D and E represent approaches in which primary healthy cells are evaluated. D, Bulk sequencing of cultures of primary human cells that were in vitro exposed to 
Postprint manuscript - accepted version

chemotherapy. Quispe-Tintaya et al. developed a novel bioinformatics algorithm to define lowabundant chemotherapy-induced SVs $[3 * *, 5]$. E, Chemotherapy exposure of adult stem cell cultures after which single cells are expanded into clones for subsequent bulk sequencing $\left[34^{* *}, 35^{*}, 36\right]$. 


\section{References}

Papers of particular interest, published within the annual period of review, (18 months/2019-2020) have been highlighted as:

* of special interest

** of outstanding interest

1. Nygren P. Acta Oncologica What is cancer chemotherapy? 2009

2. Shahrasbi A, Armin A, Ardebili A, et al. Hematologic Adverse Effects following Systemic Chemotherapy. 2017.

3. ** Quispe-Tintaya W, Lee $\mathrm{M}$, Dong $\mathrm{X}$, Weiser DA, et al. Bleomycin-induced genome structural variations in normal, non-tumor cells. Sci Rep [Internet]. 2018

This study demonstrates the use of primary human dermal fibroblasts to characterize the genotoxic effects of bleomycin treatment via bulk sequencing via a newly developed algorithm to identify low-frequent mutations from low-pass sequencing data.

4. Mishima M. Chromosomal aberrations, clastogens vs aneugens. Front Biosci - Sch [Internet]. 2017

5. Quispe-Tintaya W, Gorbacheva T, Lee M, et al. Quantitative detection of low-abundance somatic structural variants in normal cells by high-throughput sequencing. Nat Methods [Internet]. 2016

6. Tomasetti C, Vogelstein B, Parmigiani G. Half or more of the somatic mutations in cancers of self-renewing tissues originate prior to tumor initiation. Proc Natl Acad Sci U S A [Internet]. 2013

7. Iyer NS, Balsamo LM, Bracken MB, Kadan-Lottick NS. Chemotherapy-only treatment effects on long-term neurocognitive functioning in childhood ALL survivors: A review and meta-analysis. Blood [Internet]. 2015

8. Henderson TO, Ness KK, Cohen HJ. Accelerated Aging among Cancer Survivors: From Pediatrics to Geriatrics. Am Soc Clin Oncol Educ B [Internet]. 2014

9. Vyas N, Yiannakis D, Turner A, Sewell GJ. Occupational exposure to anti-cancer drugs: A review of effects of new technology [Internet]. Vol. 20, Journal of Oncology Pharmacy Practice. SAGE Publications Ltd; 2014

10. Suspiro A, Prista J. Biomarkers of occupational exposure do anticancer agents: A minireview [Internet]. Vol. 207, Toxicology Letters. Toxicol Lett; 2011

11. Kopjar N, Milas I, Garaj-Vrhovac V, Gamulin M. Alkaline comet assay study with breast cancer patients: Evaluation of baseline and chemotherapy-induced DNA damage in non-target cells. Clin Exp Med [Internet]. 2006

12. Padjas A, Lesisz D, Lankoff A, et al. Cytogenetic damage in lymphocytes of patients undergoing therapy for small cell lung cancer and ovarian carcinoma. Toxicol Appl Pharmacol [Internet]. 2005

13. Elsendoorn TJ, Weijl NI, Mithoe S, et al. Chemotherapy-induced chromosomal damage in peripheral blood lymphocytes of cancer patients supplemented with antioxidants or placebo. Mutat Res - Genet Toxicol Environ Mutagen [Internet]. 2001

14. Acar H, Çalikan Ü, Demirel S, Largaespada DA. Micronucleus incidence and their chromosomal 
origin related to therapy in acute lymphoblastic leukemia (ALL) patients: Detection by micronucleus and FISH techniques. Teratog Carcinog Mutagen [Internet]. 2001

15. Torres-Bugarín O, Ventura-Aguilar A, Zamora-Perez A, et al. Evaluation of cisplatin + 5-FU, carboplatin $+5-\mathrm{FU}$, and ifosfamide + epirubicine regimens using the micronuclei test and nuclear abnormalities in the buccal mucosa. Mutat Res - Genet Toxicol Environ Mutagen [Internet]. 2003

16. Saini N, Gordenin DA. Somatic mutation load and spectra: A record of DNA damage and repair in healthy human cells [Internet]. Vol. 59, Environmental and Molecular Mutagenesis. John Wiley and Sons Inc.; 2018

17. ** Pich O, Muiños F, Lolkema MP, et al. The mutational footprints of cancer therapies. Nat Genet [Internet]. 2019

Using metastatic tumor samples, in vivo exposed to different chemotherapeutics, the mutational footprint of carboplatin, cisplatin, oxaliplatin, capecitabine and 5-fluorouracil, was mapped. It gives a comprehensive overview of mutations induced by this selection of drugs in human-derived metastatic tumor samples.

18. * Lee-Six H, $\varnothing$ bro NF, Shepherd MS, et al. Population dynamics of normal human blood inferred from somatic mutations. Nature [Internet]. 2018

Since chemotherapy-induced mutations occur at very low frequency across tissue cells, their variant allele frequency (VAF) may fall below the detection limit of standard bulk sequencing which makes cataloguing these low-frequent DNA aberrations from bulk normal noncancerous cells in vivo highly challenging.

19. Boere I, Lok C, Vandenbroucke T, Amant F. Cancer in pregnancy: Safety and efficacy of systemic therapies [Internet]. Vol. 29, Current Opinion in Oncology. Lippincott Williams and Wilkins; 2017

20. Pavlidis NA. Coexistence of pregnancy and malignancy. Oncologist. 2002;7(4):279-87.

21. Van Calsteren K, Heyns L, Amant F, et al. Transplacental transfer of paclitaxel, docetaxel, carboplatin, and trastuzumab in a baboon model. Int J Gynecol Cancer [Internet]. 2010

22. Van Calsteren K, Hartmann D, Van Aerschot L, et al. Vinblastine and doxorubicin administration to pregnant mice affects brain development and behaviour in the offspring. Neurotoxicology [Internet]. 2009

23. Van Calsteren $\mathrm{K}$, Verbesselt $\mathrm{R}$, Van Bree $\mathrm{R}$, et al. Substantial variation in transplacental transfer of chemotherapeutic agents in a mouse model. Reprod Sci [Internet]. 2011

24. Berveiller $\mathrm{P}$, Vinot $\mathrm{C}$, Mir $\mathrm{O}$, et al. Comparative transplacental transfer of taxanes using the human perfused cotyledon placental model. Am J Obstet Gynecol [Internet]. 2012

25. Koc ON, McFee M, Reed E, Gerson SL. Detection of platinum-DNA adducts in cord blood lymphocytes following in utero platinum exposure. Eur J Cancer. 1994;30A(5):716-7.

26. Köhler $C$, Oppelt $P$, Favero $G$, et al. How much platinum passes the placental barrier? Analysis of platinum applications in 21 patients with cervical cancer during pregnancy. Am J Obstet Gynecol [Internet]. 2015

27. Van Calsteren $\mathrm{K}$, Verbesselt $\mathrm{R}$, Beijnen J, et al. Transplacental transfer of anthracyclines, vinblastine, and 4-hydroxy-cyclophosphamide in a baboon model. Gynecol Oncol [Internet]. 2010 
28. Amant F, Berveiller P, Boere IA, et al. Gynecologic cancers in pregnancy: Guidelines based on a third international consensus meeting [Internet]. Vol. 30, Annals of Oncology. Oxford University Press; 2019

29. Maslov AY, Quispe-Tintaya W, Gorbacheva T, et al. High-throughput sequencing in mutation detection: a new generation of genotoxicity tests?

30. $* *$ Kucab JE, Zou X, Morganella S, et al. A Compendium of Mutational Signatures of Environmental Agents. Cell [Internet]. 2019

Using iPSC lines, in vitro exposed to different chemotherapeutics and outgrowht in to single clones, the mutational footprint of cisplatin, carboplatin \& cyclophosphamide, was mapped. It gives a comprehensive overview of mutations induced by this selection of drugs in humanderived stem cell lines.

31. von Joest M, Búa Aguín S, Li H. Genomic stability during cellular reprogramming: Mission impossible? Mutat Res - Fundam Mol Mech Mutagen. 2016 Jun 1;788:12-6.

32. ** Boot A, Huang MN, Ng AWT, et al. In-depth characterization of the cisplatin mutational signature in human cell lines and in esophageal and liver tumors. Genome Res [Internet]. 2018

This study demonstrates the use of human derived cell lines to characterize the genotoxic effects of cisplatin treatment by using a single-cell approach in which bulk sequencing is performed on clonal outgrowths of single cells.

33. Carter M, Shieh J. Guide to Research Techniques in Neuroscience: Cell culture techniques. 2015

34. ** Christensen $\mathrm{S}$, Van der Roest B, Besselink N, et al. 5-Fluorouracil treatment induces characteristic T>G mutations in human cancer. Nat Commun [Internet]. 2019

This study demonstrates the use of primary human cells to characterize the genotoxic effects of 5-fluorouracil treatment by using a single-cell approach in which bulk sequencing is performed on clonal outgrowths of single cells.

35. * Jager M, Blokzijl F, Sasselli V, et al. Measuring mutation accumulation in single human adult stem cells by whole-genome sequencing of organoid cultures. Nat Protoc [Internet]. 2018

This study shows that mutations arising in healthy tissues can be identified by culturing stem cells into organoids to overcome the limitation of identifying low-frequent mutations.

36. Blokzijl F, De Ligt J, Jager M, et al. Tissue-specific mutation accumulation in human adult stem cells during life. Nature [Internet]. 2016

37. Dou Y, Gold HD, Luquette L, Park PJ. Detecting Somatic Mutations in Normal Cells [Internet]. Vol. 34, Trends in Genetics. Elsevier Ltd; 2018

38. Vandenbroucke $T$, Verheecke $M$, van Gerwen $M$, et al. Child development at 6 years after maternal cancer diagnosis and treatment during pregnancy. Eur J Cancer [Internet]. 2020

39. Amant $F$, Vandenbroucke $T$, Verheecke $M$, et al. Pediatric Outcome after Maternal Cancer Diagnosed during Pregnancy. N Engl J Med [Internet]. 2015

40. Blommaert J, Radwan A, Sleurs C, et al. The impact of cancer and chemotherapy during pregnancy on child neurodevelopment: A multimodal neuroimaging analysis. EClinicalMedicine [Internet]. 2020

41. de Haan J, Verheecke $\mathrm{M}$, Van Calsteren $\mathrm{K}$, et al. Oncological management and obstetric and neonatal outcomes for women diagnosed with cancer during pregnancy: a 20-year 
international cohort study of 1170 patients. Lancet Oncol [Internet]. 2018

42. Lees C. Perinatal morbidity and mortality in early-onset fetal growth restriction: cohort outcomes of the trial of randomized umbilical and fetal flow in Europe (TRUFFLE). Ultrasound Obstet Gynecol.

43. Verheecke M, Cortès Calabuig A, Finalet Ferreiro J, et al. Genetic and microscopic assessment of the human chemotherapy-exposed placenta reveals possible pathways contributive to fetal growth restriction. Placenta [Internet]. 2018

44. Avilés A, Neri N, Nambo MJ. Hematological malignancies and pregnancy: Treat or no treat during first trimester. Int J Cancer [Internet]. 2012

45. * Cardonick E, Eicheldinger E, Gaughan J. Chemotherapy is avoided during the first trimester of pregnancy, when is the safest time to start treatment during the second or third trimester? ProClinS Gynecol Obstet [Internet]. 2019

Chemotherapy is considered safe during pregnancy, although care should be taken regarding the timing of starting therapy since this could lead to an increased risk of congenital anomalies when started during the first trimester of pregnancy.

46. Gomez-Mariscal K, Gómez-Meda BC, Zamora-Perez AL, et al. Micronuclei induction in amniotic fluid cells from cyclophosphamide treated rats. Ann Clin Lab Sci [Internet]. 2018

47. Prakash, Gupta V, Singh SM, et al. Effect of intrauterine exposure of murine fetus to cyclophosphamide on development of thymus. Immunopharmacol Immunotoxicol [Internet]. 2007

48. Tripathi DN, Pawar AA, Vikram A, et al. Use of the alkaline comet assay for the detection of transplacental genotoxins in newborn mice. Mutat Res - Genet Toxicol Environ Mutagen. 2008 May 31;653(1-2):134-9.

49. Nam C, Yamauchi H, Nakayama H, Doi K. Etoposide induces apoptosis and cell cycle arrest of neuroepithelial cells in a p53-related manner. Neurotoxicol Teratol [Internet]. 2006

50. Gómez-Meda BC, Zamora-Perez AL, Ramos-Ibarra ML, et al. Micronucleated erythrocytes in peripheral blood of newborn rabbits after exposure to cyclophosphamide during pregnancy. Scand J Lab Anim Sci. 2008;35(3):151-8.

51. Malassiné A, Frendo JL, Evain-Brion D. A comparison of placental development and endocrine functions between the human and mouse model [Internet]. Vol. 9, Human Reproduction Update. Hum Reprod Update; 2003

52. Franco I, Helgadottir HT, Moggio A, et al. Whole genome DNA sequencing provides an atlas of somatic mutagenesis in healthy human cells and identifies a tumor-prone cell type. Genome Biol [Internet]. 2019 
Postprint manuscript - accepted version 
Postprint manuscript - accepted version 
Postprint manuscript - accepted version 
Table 1 : Different classes of chemotherapeutic agents with their mode of action, specific effect on DNA and known mutational signature induced in surrogate normal tissue

\begin{tabular}{|c|c|c|c|c|c|}
\hline Class of agent & Examples & $\begin{array}{l}\text { Reactivity } \\
\text { class }\end{array}$ & Effect on DNA molecule & Mode of action & $\begin{array}{l}\text { Mutational signature in surrogate normal } \\
\text { tissue/cells }\end{array}$ \\
\hline $\begin{array}{l}\text { Alkylating } \\
\text { agents }\end{array}$ & $\begin{array}{l}\text { Nitrogen mustards } \\
\text { (Cyclophosphamide, } \\
\text { ifosfamide, chlorambucil), } \\
\text { platinum-based agents } \\
\text { (cisplatin, carboplatin), } \\
\text { dacarbazine }\end{array}$ & DNA-reactive & $\begin{array}{l}\text { Covalent DNA-adducts } \\
\text { and DNA-crosslinks }\end{array}$ & $\begin{array}{l}\text { Inhibit DNA replication } \\
\text { process }\end{array}$ & 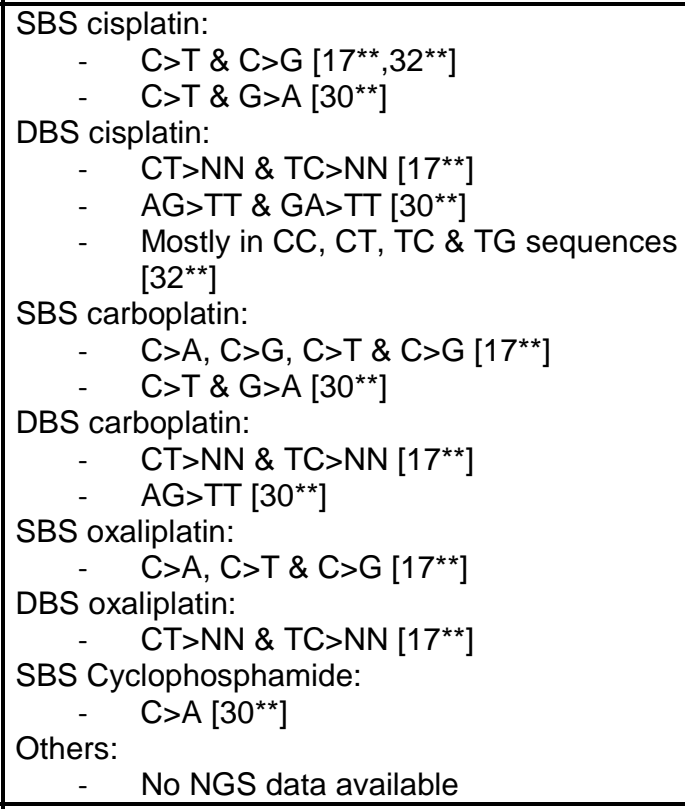 \\
\hline $\begin{array}{l}\text { Topoisomerase } \\
\text { inhibitors }\end{array}$ & $\begin{array}{l}\text { Anthracyclines } \\
\text { (Doxorubicin, epirubicin), } \\
\text { etoposide }\end{array}$ & DNA-reactive & $\begin{array}{l}\text { Covalent DNA-adducts, } \\
\text { Single and double DNA } \\
\text { strand breaks }\end{array}$ & $\begin{array}{l}\text { Prevent religation of DNA } \\
\text { molecules after } \\
\text { topoisomerase activity or } \\
\text { enhance topoisomerase } \\
\text { activity }\end{array}$ & $\begin{array}{l}\text { Etoposide: } \\
-\quad \text { No detectable signature found }\left[30^{* *}\right] \\
\text { Anthracyclines: } \\
\quad \text { No NGS data available }\end{array}$ \\
\hline $\begin{array}{l}\text { Microtubule } \\
\text { interacting } \\
\text { agents }\end{array}$ & $\begin{array}{l}\text { Taxanes (Paclitaxel, } \\
\text { docetaxel), Vinca } \\
\text { alkaloids (vinblastine, } \\
\text { vincristine) }\end{array}$ & $\begin{array}{l}\text { DNA non- } \\
\text { reactive }\end{array}$ & $\begin{array}{l}\text { Interference with } \\
\text { intracellular trafficking of } \\
\text { DNA-repair proteins }\end{array}$ & $\begin{array}{l}\text { Polymerisation and/or } \\
\text { stabilization of microtubules } \\
\text { or depolimerisation and/or } \\
\text { destabilization of microtubules }\end{array}$ & \begin{tabular}{|l} 
Taxanes: \\
$-\quad$ No NGS data available \\
Vinca alkaloids: \\
$-\quad$ No NGS data available
\end{tabular} \\
\hline
\end{tabular}




\begin{tabular}{|c|c|c|c|c|c|}
\hline $\begin{array}{l}\text { DNA strand } \\
\text { breaking agents }\end{array}$ & Bleomycin & DNA-reactive & $\begin{array}{l}\text { Single and double DNA } \\
\text { strand breaks }\end{array}$ & $\begin{array}{l}\text { Induction of DNA strand } \\
\text { breaks }\end{array}$ & \begin{tabular}{|l} 
Bleomycin: \\
- Increased fraction of interchromosomal \\
SVs and reduced fraction of \\
intrachromosomal SVs in proliferating \& \\
quiescent primary human fibroblast $\left[3^{\star \star}\right]$ \\
- \\
No detectable signature found [30*]
\end{tabular} \\
\hline
\end{tabular}


Table 2: Animal studies investigating genotoxic effects of prenatal exposure to chemotherapy using in vitro cytogenetic testing.

\begin{tabular}{|c|c|c|c|c|c|c|c|c|}
\hline Class & Compound & $\begin{array}{l}\text { Test } \\
\text { species }\end{array}$ & Test tissue & $\begin{array}{l}\text { GA at } \\
\text { administration } \\
\text { (days) }\end{array}$ & $\begin{array}{l}\text { GA at } \\
\text { tissue } \\
\text { sampling }\end{array}$ & Test & Outcome & Reference \\
\hline Alkylating agent & Cyclophosphamide & Rabbit & $\begin{array}{l}\text { Peripheral } \\
\text { tail blood } \\
\text { from the } \\
\text { newborn }\end{array}$ & $\begin{array}{l}25-30 \text { (end of } \\
\text { organogenesis) }\end{array}$ & Birth & $\begin{array}{l}\text { Micronucleus } \\
\text { assay }\end{array}$ & $\begin{array}{l}\text { Significant increase in micronucleus } \\
\text { frequency indicates increase of } \\
\text { chromosomal loss or breakage. } \\
\text { No significant difference in PCE } \\
\text { values indicates no observable } \\
\text { cytotoxicity of cyclophosphamide to } \\
\text { the cells }\end{array}$ & {$[50]$} \\
\hline Alkylating agent & Cyclophosphamide & Mouse & $\begin{array}{l}\text { Newborn } \\
\text { lymphocytes, } \\
\text { bone } \\
\text { marrow, liver } \\
\text { \& kidney } \\
\text { cells }\end{array}$ & $\begin{array}{l}16-20 \text { (late } \\
\text { gestational } \\
\text { period) }\end{array}$ & Birth & $\begin{array}{l}\text { Alkaline } \\
\text { COMET assay } \\
\& \\
\text { micronucleus } \\
\text { assay }\end{array}$ & $\begin{array}{l}\text { Significant increase in micronucleus } \\
\text { frequency indicates increase of } \\
\text { chromosomal loss or breakage; } \\
\text { COMET assay results indicate } \\
\text { significant increase of DNA strand } \\
\text { breaks }\end{array}$ & [48] \\
\hline Alkylating agent & Cyclophosphamide & Mouse & Fetal thymus & 11 & 19 days & $\begin{array}{l}\text { DNA } \\
\text { fragmentation } \\
\& \text { MTT cell } \\
\text { viability assay }\end{array}$ & $\begin{array}{l}\text { Significant increase of DNA } \\
\text { fragmentation \& significant inhibition } \\
\text { in thymocyte proliferation }\end{array}$ & {$[47]$} \\
\hline Alkylating agent & Cyclophosphamide & Rat & $\begin{array}{l}\text { Amniotic } \\
\text { fluid cells }\end{array}$ & $14-18$ & 19 days & $\begin{array}{l}\text { Micronucleus } \\
\text { assay }\end{array}$ & $\begin{array}{l}\text { Significant increase in micronucleus } \\
\text { frequency indicates increase of } \\
\text { chromosomal loss or breakage }\end{array}$ & [46] \\
\hline $\begin{array}{l}\text { Topoisomerase } \\
\text { inhibitor }\end{array}$ & Etoposide & Mouse & Fetal brain & 12 & $\begin{array}{l}1,2,4,8 \\
12,24 \& \\
48 h \text { after } \\
\text { treatment }\end{array}$ & $\begin{array}{l}\text { cell cycle } \\
\text { analysis, DNA } \\
\text { microarray \& } \\
\text { RT-PCR }\end{array}$ & $\begin{array}{l}\text { S-phase accumulation, G2/M arrest } \\
\& \text { apoptosis of neural progenitor } \\
\text { cells in fetal telencephalon }\end{array}$ & [49] \\
\hline
\end{tabular}

